\title{
Management of Botrytis Fruit Rot in Annual Winter Strawberry Using Captan, Thiram, and Iprodione
}

\author{
D. E. Legard, C. L. Xiao, J. C. Mertely, and C. K. Chandler, University of Florida, Gulf Coast Research and \\ Education Center, 13138 Lewis Gallagher Road, Dover 33527
}

\begin{abstract}
Legard, D. E., Xiao, C. L., Mertely, J. C., and Chandler, C. K. 2001. Management of Botrytis fruit rot in annual winter strawberry using captan, thiram, and iprodione. Plant Dis. 85:31-39.

The management of Botrytis fruit rot on annual strawberry by fungicides was evaluated in Florida during the 1995-96, 1996-97, and 1997-98 seasons. Weekly applications of captan or thiram, bloom applications of iprodione applied twice during each of two peak flowering periods, and weekly applications of captan combined with iprodione bloom applications were evaluated. Significant treatment effects $(P \leq 0.05)$ on the incidence of Botrytis fruit rot were detected for the early, late, and whole-season periods each season. Weekly applications of captan or thiram controlled Botrytis fruit rot, reducing disease incidence by more than $41 \%$ compared to the untreated control. These treatments also affected marketable yield during two seasons, with a 42 to $127 \%$ increase in yield compared to the control. Weekly fungicide applications did not reduce the incidence of Botrytis fruit rot until at least the fourth week of harvest, 9 to 10 weeks after applications began. Bloom applications of iprodione alone reduced the incidence of Botrytis fruit rot during the second peak bloom period, and the reductions in incidence occurred 1 to 3 weeks after the start of bloom applications. This suggests that iprodione applications control infections at flowering or early stages of fruit development. However, early-season bloom applications did not reduce the incidence of Botrytis fruit rot. The control of Botrytis fruit rot by weekly captan applications was not improved by the addition of iprodione bloom applications. These data suggest that early-season fungicide applications for the control of Botrytis fruit rot in annual winter strawberry are of limited efficacy, and that bloom applications of Botryticides such as iprodione should be focused on the second peak bloom period.
\end{abstract}

Florida is the major producer of winter strawberries for the Eastern U.S. and Canadian markets. In Florida, strawberries are produced as an annual crop in methyl bromide-fumigated plastic-mulched raised beds. Botrytis fruit rot (Botrytis cinerea) is the most important disease affecting the crop, causing preharvest losses of up to $15 \%$ of the fruit on susceptible cultivars (14-16).

Little is known about the dynamics of Botrytis fruit rot epidemics in annual strawberry production systems. In perennial systems, epidemics of Botrytis fruit rot are primarily initiated by conidia produced on dead strawberry leaves within the field (5). Young, expanding strawberry leaves are quiescently infected by the pathogen and, as the leaf senesces, $B$. cinerea colo-

Corresponding author: D. E. Legard

E-mail: legard@ufl.edu

Florida Agricultural Experiment Station Journal Series No. R-07525. This research was supported by the Pesticide Impact Assessment Program.

Current address of C. L. Xiao: Washington State University, Tree Fruit Research and Extension Center, Wenatchee 98801.

Accepted for publication 18 September 2000.

Publication no. D-2000-1025-02R

(C) 2001 The American Phytopathological Society nizes the dying tissues and sporulates (6). Conidia are air or water dispersed to flowers (23), where they infect floral parts $(7,21)$ and decay ripening fruit. Direct infection of fruit by conidia is not considered important $(13,23)$. After initiation of the epidemic, diseased flowers, fruit, and senescent foliage serve as important sources of secondary inocula in annual production systems (18).

Strategies for chemical control of Botrytis fruit rot focus on protecting flowers $(13,25)$ or foliage from infection or reducing sporulation of the pathogen on infected plant material $(3,6)$. In perennial systems, fungicide applications in the fall reduced the sporulation of $B$. cinerea on leaves during the following June, when the plants were in bloom $(3,4)$. Effective control of Botrytis fruit rot was obtained with bloom applications of fungicides (25). Captan, thiram, and iprodione have been reported to control Botrytis fruit rot on strawberry in perennial $(9,24)$ production systems. Only preliminary reports document the effectiveness of these fungicides in subtropical annual production systems $(2,11$, 12,14,15).

In annual strawberry production systems, Botrytis fruit rot is controlled by a combination of cultural and chemical methods. Although no cultivar is completely resistant to Botrytis fruit rot, there are significant differences in susceptibility among cultivars used commercially in Florida (16). Cultural practices such as sanitation or modification of the canopy microclimate can also improve the control of Botrytis fruit rot. Commercial growers often remove senescent foliage after plant establishment, which reduces the incidence of Botrytis fruit rot when fungicides are not applied (19). Growers also use drip instead of overhead irrigation to reduce free moisture and to prevent splash dispersal of pathogens. Growing strawberries under clear plastic tunnels also reduces leaf wetness duration and Botrytis fruit rot incidence (26). Reducing plant density by using wider plant spacing reduces the incidence of Botrytis fruit rot (16).

Due to high disease pressure from Botrytis fruit rot and other diseases in Florida, disease management has been heavily reliant on fungicides. Growers in Florida can apply captan, a protectant fungicide, up to 24 times ( 2.3 to $3.4 \mathrm{~kg}$ a.i./ha) during the season. Even with regular fungicide applications, Botrytis fruit rot can still cause severe losses on highly susceptible cultivars (16). Although strawberries flower throughout the winter in Florida, there are typically two peak flowering periods each season, one in November or December and the other in mid- to late January (16). The first bloom period typically produces fruit when market prices are the highest, and the second bloom period produces a majority of marketable fruit for the season. Because flowers are the primary means of fruit infection, a program combining weekly captan or thiram applications with supplemental applications of iprodione during peak bloom periods may improve control.

The purpose of this study was to evaluate the efficacy of weekly captan and thiram applications and bloom applications of iprodione in the control of Botrytis fruit rot in annual strawberry, and to evaluate a combined weekly captan and iprodione bloom application treatment. A preliminary report has been published (17).

\section{MATERIALS AND METHODS}

Field experiments were conducted at the University of Florida, Gulf Coast Research and Education Center-Dover, during the 1995-96, 1996-97, and 1997-98 seasons. Each season, nondefoliated, bareroot strawberry plants of cv. Sweet Charlie, produced in Canada, were transplanted into plastic-mulch raised beds on $1.22-\mathrm{m}$ centers $(71 \mathrm{~cm}$ wide, $18 \mathrm{~cm}$ high at the center, 
and $15 \mathrm{~cm}$ high at the edge), in methyl bromide:chloropicrin (98:2)-fumigated soil. Plants were overhead irrigated by sprinkler for 14 days to facilitate establishment, then irrigated and fertilized through drip tape for the remainder of the season. When necessary, overhead sprinkler irrigation was used to provide frost and freeze protection. Fungicide treatments were applied with a $\mathrm{CO}_{2}$ backpack sprayer using a two-nozzle wand (935 liters/ha, $310 \mathrm{kPa}$ ).

Treatments that included weekly fungicide applications were started immediately after plant establishment and continued until the final harvest. Bloom applications of iprodione were made during the first two peak flowering periods each season, when 10 to $20 \%$ of the flowers had opened, and again 7 days later (approximately 50 to $75 \%$ bloom). Bloom applications were intended to protect a majority of flowers during the first two fruit sets. Captan was applied separately from iprodione when both fungicides were applied to a treatment. Fruit were harvested and immediately graded twice weekly each season. The number of marketable fruit and their weight (marketable yield), unmarketable fruit count, and the number of fruit with Botrytis rot were determined each harvest. The experiments were arranged in a randomized complete block design with four replications.

For the 1995-96 season, transplanting was done on 18 October 1995. Plots consisted of 16 plants set in two-row beds, 30 $\mathrm{cm}$ apart within and between rows. The experiment evaluated four treatments: untreated control, weekly applications of captan (3.4 kg a.i./ha), weekly applications of thiram (1.8 kg a.i./ha), and weekly applications of captan (3.4 kg a.i./ha), plus four bloom applications of iprodione (1.1 $\mathrm{kg}$ a.i./ha). Fungicides were applied weekly from 1 November 1995 to 25 March 1996. Fungicide applications for the first bloom were applied on 29 November and 6 December, and for the second bloom on 23 January and 30 January. Fruit were harvested and graded from 8 December 1995 through 25 March 1996 (32 harvests).

For the 1996-97 season, transplanting was done on 18 October 1996. Plots consisted of 18 plants in two-row beds, $30 \mathrm{~cm}$ apart within and between rows. The experiment had five treatments: untreated control, weekly applications of captan (3.4 $\mathrm{kg}$ a.i./ha), weekly applications of thiram (1.8 kg a.i./ha), and weekly applications of captan (3.4 kg a.i./ha), plus four bloom applications of iprodione (1.1 kg a.i./ha); and four applications of iprodione alone (1.1 kg a.i./ha). The weekly fungicide treatments were applied from 14 November through 4 March. Iprodione was applied on 27 November and 4 December for the first bloom, and on 14 January and 21 January for the second bloom. Fruit were harvested and graded from 20 December through 6 March (23 harvests).
For the 1997-98 season, 16 plants were set per plot in two-row beds, $30 \mathrm{~cm}$ apart within and between rows on 7 October 1997. The experiment had the same five treatments as 1996-97. Weekly fungicide treatments were applied from 30 October 1996 through 10 March 1997. Fungicides for the first bloom were applied on $18 \mathrm{No}$ vember and 25 November and for the second bloom on 13 January and 20 January. Fruit were harvested and graded from 1 December 1997 through 12 March 1998 (30 harvests).

Cumulative Botrytis fruit rot incidence (number of fruit with Botrytis rot divided by the total number of fruit harvested during a period) and marketable yield were calculated for early, late, and whole-season periods. Fruit harvested up to and including the week the second set of bloom applications began were included in the early period (weeks 1 to 8, 1995-96; weeks 1 to 5, 1996-97; and weeks 1 to 7, 1997-98). All fruit harvested after that week were included in the late period (weeks 9 to 17 , 1995-96; weeks 6 to 12, 1996-97; and weeks 8 to $15,1997-98)$. Totals for the whole season (early and late periods combined) were also calculated. Analyses of variance were performed using SAS (SAS Institute Inc., Cary, NC). Incidence of Botrytis fruit rot data were transformed (arcsine square root) prior to analysis. Mean comparisons were made using Fisher's protected least significant difference (LSD; $P \leq 0.05$ ).

To provide a detailed analysis of treatment effects over time, repeated measures analyses of variance $(8,10)$ were performed on weekly (each week's harvest) and cumulative (all harvests up to and including that week) incidence of Botrytis fruit rot and marketable yield using the SAS general linear model procedure (proc GLM) with repeated option. Weekly Botrytis fruit rot incidence was expressed as the average percentage of Botrytis fruit rot for the two harvests during each weekly period. $\mathrm{Cu}$ mulative Botrytis fruit rot incidence can decrease over time because incidence is calculated as a running average. For the 1995-96 and 1996-97 seasons, only one harvest occurred during the first weekly interval (week 1), and during the 1995-96 season, there was only one harvest during the last weekly interval (week 17). Independent analyses of variance were also conducted for each harvest week (weekly and cumulative data) and mean comparisons were made using Fisher's protected $\operatorname{LSD}(P \leq 0.05)$.

\section{RESULTS}

Development of Botrytis fruit rot epidemics and marketable yield patterns. The development of the Botrytis fruit rot epidemics was similar each season, although their severity varied (Fig. 1). The incidence of Botrytis rot was initially low and then peaked during mid- to late season.
During the 1995-96 season, the incidence of Botrytis fruit rot reached a weekly peak of $18 \%$ (week 11) and a cumulative peak of $6.9 \%$ (week 14) in the untreated control. During the 1996-97 season, the incidence of Botrytis rot was higher than in 1995-96, with a weekly peak of 53\% (week 7) and a cumulative peak of $26 \%$ (week 10) for the untreated control. During the 1997-98 season, Botrytis rot incidence was also high, with a weekly peak of $66 \%$ (week 11) and a cumulative peak of $41 \%$ (week 13) for the control.

Marketable yields peaked at similar times each season (Fig. 2). During the 1995-96 season, the first harvest peak occurred during week 3,3 weeks after the beginning of the first two bloom applications, and the second peak harvest was during week 13,5 weeks after the beginning of the second pair of bloom applications. During the 1996-97 season, the first harvest peak occurred during week 3,5 weeks after the beginning of the first pair of bloom applications, and the second harvest peak was during weeks 9 and 10,4 to 5 weeks after the beginning of the second pair of bloom applications. During the 1997-98 season, the first harvest peak occurred during week 4,5 weeks after the beginning of the first pair of bloom applications, and the second peak harvest occurred during weeks 12 and 13,5 to 6 weeks after the beginning of the second pair of bloom applications.

Incidence of Botrytis fruit rot. Significant treatment effects $(P \leq 0.05)$ on the incidence of Botrytis fruit rot were detected for the early, late, and whole-season periods each season (Table 1). During the early period in 1995-96, the captan, thiram, and the captan plus iprodione bloom spray treatments significantly reduced disease incidence compared to the untreated control. However, during the late and whole-season periods, only the captan and the captan plus iprodione treatments significantly reduced disease incidence. The addition of iprodione bloom sprays to the captan treatment did not improve the control of Botrytis fruit rot over the weekly captan treatment during 1995-96.

During the early period in 1996-97, the captan, thiram, and captan plus iprodione treatments significantly reduced the incidence of Botrytis fruit rot compared to the untreated control (Table 1). There were no differences in the control of Botrytis between the control and the iprodione-only treatment. For the late and whole-season periods, all the fungicide treatments produced significant reductions in Botrytis rot compared to the control. The captan, thiram, and captan plus iprodione treatments also significantly reduced the incidence of Botrytis fruit rot compared to the iprodione only treatment.

During the early period of 1997-98, all the fungicide treatments except the iprodione-only treatment significantly reduced 
the incidence of Botrytis fruit rot compared to the control (Table 1). For the late and whole-season periods, all the fungicide treatments significantly reduced the incidence of Botrytis fruit rot. The captan and captan plus iprodione treatments also had significantly less Botrytis fruit rot than the thiram and the iprodione only treatments.

Weekly applications of captan significantly reduced the incidence of Botrytis fruit rot compared to the control during the 1995-96, 1996-97, and 1997-98 seasons
(Table 1). Although weekly applications of thiram also reduced Botrytis rot during 1996-97 and 1997-98, they were not as efficacious as the captan treatments during the late and whole-season periods of 199798. The iprodione only treatment also
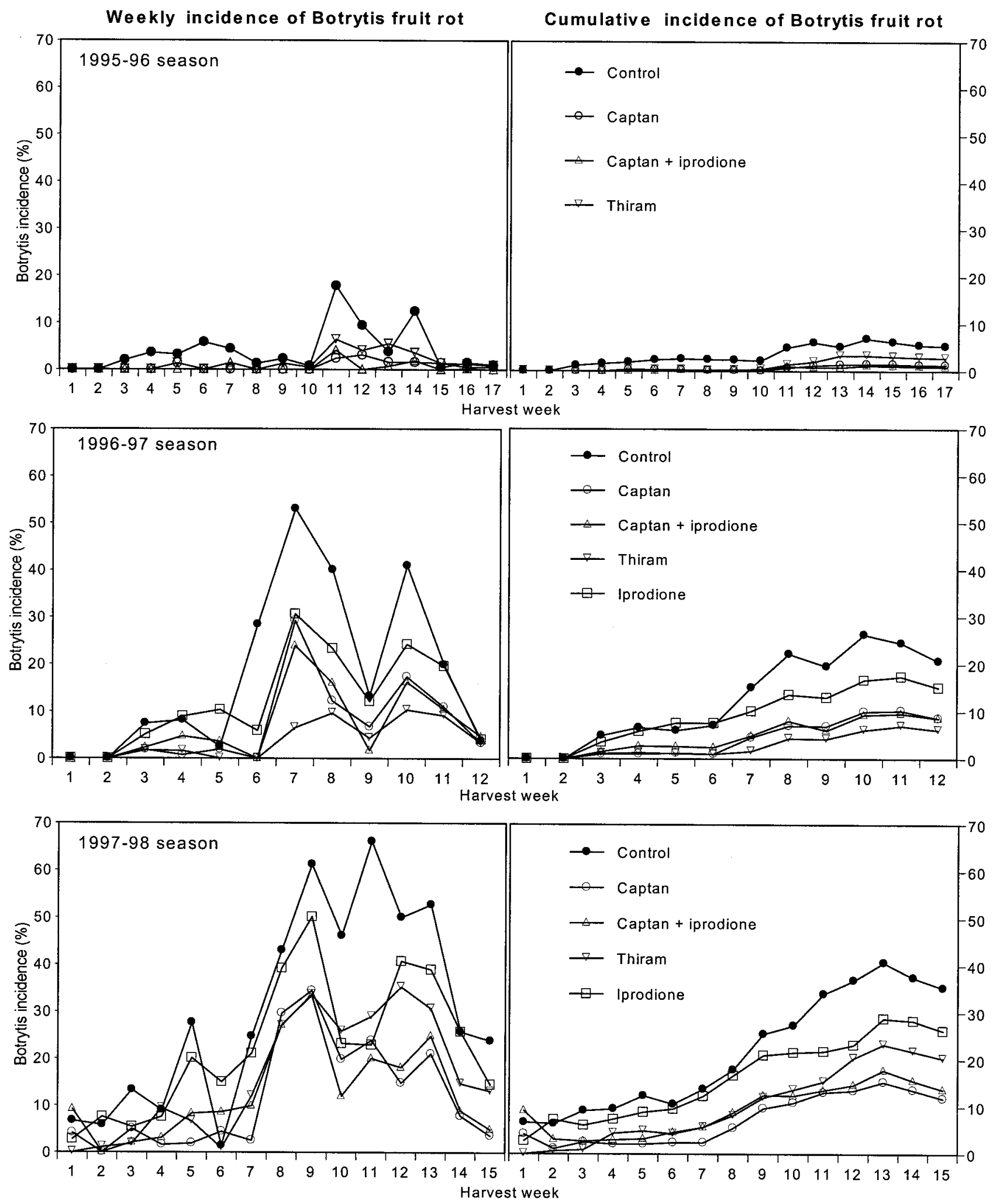

Fig. 1. Effect of different fungicide treatment programs on the weekly and cumulative incidence of Botrytis fruit rot during the 1995-96, 1996-97, and 1997-98 seasons. Cumulative Botrytis fruit rot incidence can decrease over time because incidence is calculated as a running average. Captan and thiram treatments were applied weekly throughout each season. Iprodione treatments were applied in two applications, 1 week apart during the first and second peak bloom period each season. 

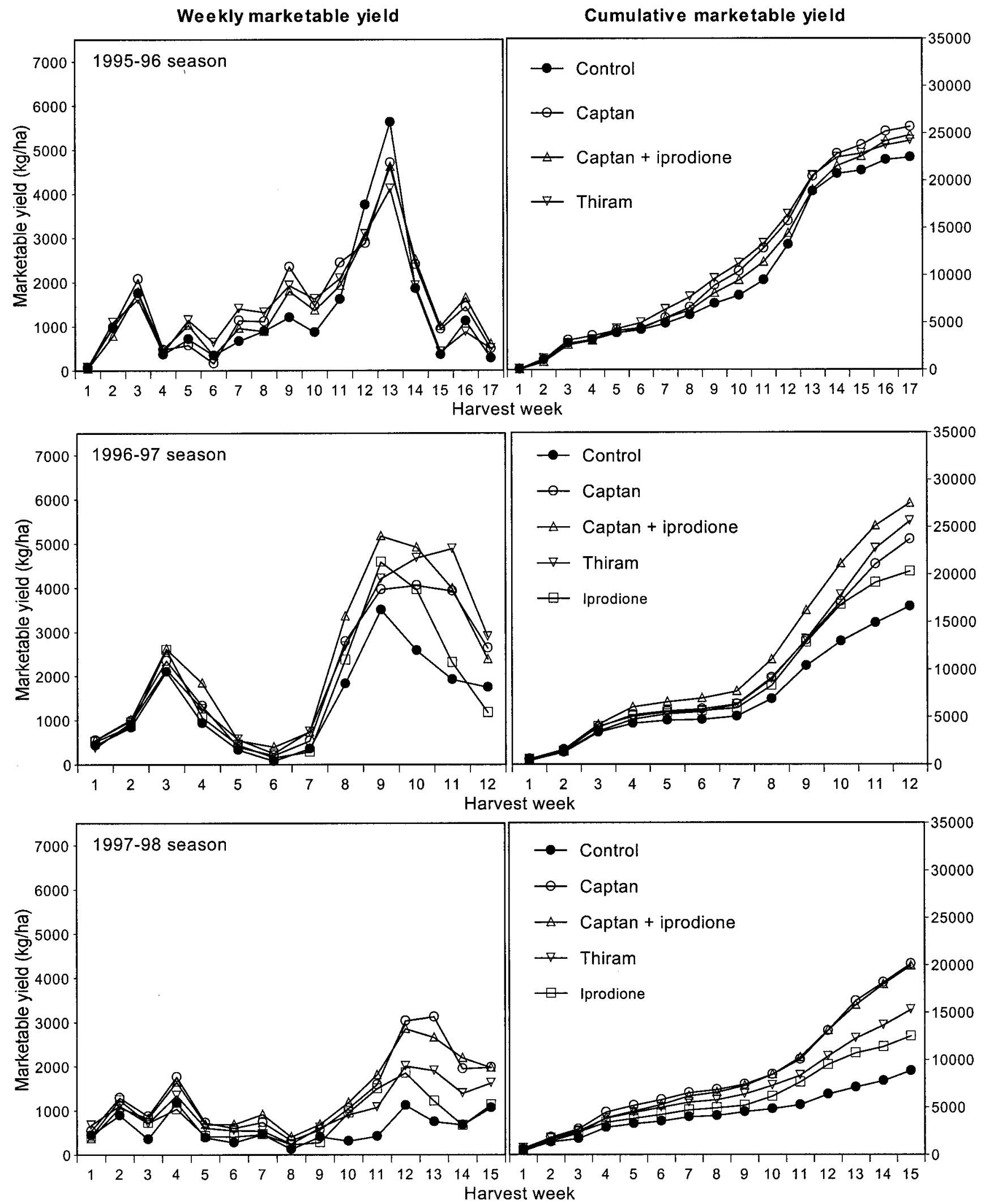

Fig. 2. Effect of different fungicide treatment programs on the weekly and cumulative marketable yield during the 1995-96, 1996-97, and 1997-98 seasons. Captan and thiram treatments were applied weekly throughout each season. Iprodione treatments were applied in two applications, 1 week apart during the first and second peak bloom period each season. 
significantly reduced Botrytis fruit rot during the late and whole-season periods of 1996-97 and 1997-98. However, this treatment did not reduce the incidence of Botrytis fruit rot compared to the control during the early period in either season. There were no significant differences in the control of Botrytis fruit rot between the captan and the captan plus iprodione treatments each season.

Marketable yield. Marketable yields were highest during 1995-96 (Table 1), but there were no significant treatment effects on yield that season, probably due to the relatively low incidence of Botrytis fruit rot. During the early period of 1996-97 (Table 1), the control plants and those treated with thiram had significantly lower marketable yields than the plants from the remaining treatments. The captan plus iprodione-treated plants had the highest yield, and the plants from the remaining treatments produced intermediate yields. For the late-season period, the control plants and the iprodione-only-treated plants produced significantly lower yields than the plants from the other treatments. For the whole season, the untreated control plants produced the lowest yield, followed by the plants treated with only iprodione. The plants treated with captan plus iprodione or thiram produced the highest yields, and plants treated with captan produced intermediate yield.
During the early period of 1997-98, plants treated with thiram, iprodione only, and the control plants produced equivalent marketable yields (Table 1). The captan and captan plus iprodione-treated plants produced the highest yields, although they were not significantly different from the thiram-treated plants. Yields for the captan plus iprodione and the iprodione-onlytreated plants were not statistically different. For the late and whole-season periods, the marketable yield was highest for the captan and the captan plus iprodionetreated plants and lowest for the control plants.

Weekly incidence and weekly cumulative incidence of Botrytis fruit rot and

Table 1. Botrytis fruit rot incidence and marketable yield for each period during the 1995-96, 1996-97, and 1997-98 seasons ${ }^{\mathrm{v}}$

\begin{tabular}{|c|c|c|c|c|c|c|c|c|c|}
\hline \multirow[b]{2}{*}{ Treatments $^{\mathrm{z}}$} & \multicolumn{3}{|c|}{ Early period $^{w}$} & \multicolumn{3}{|c|}{ Late period $^{x}$} & \multicolumn{3}{|c|}{ Whole season ${ }^{y}$} \\
\hline & 1995-96 & 1996-97 & 1997-98 & 1995-96 & 1996-97 & 1997-98 & $1995-96$ & 1996-97 & $1997-98$ \\
\hline \multicolumn{10}{|l|}{ Rot incidence (\%) } \\
\hline Control & $2.5 \mathrm{~b}$ & $6.0 \mathrm{c}$ & $13.8 \mathrm{~b}$ & $5.8 \mathrm{~b}$ & $23.6 \mathrm{c}$ & $41.7 \mathrm{~d}$ & $5.3 \mathrm{~b}$ & $20.7 \mathrm{c}$ & $35.3 \mathrm{~d}$ \\
\hline Captan & $0.2 \mathrm{a}$ & $1.2 \mathrm{a}$ & $2.4 \mathrm{a}$ & $1.4 \mathrm{a}$ & $10.0 \mathrm{a}$ & $14.1 \mathrm{a}$ & $1.3 \mathrm{a}$ & $8.6 \mathrm{a}$ & $11.8 \mathrm{a}$ \\
\hline Captan + iprodione & $0.2 \mathrm{a}$ & $2.6 \mathrm{ab}$ & $5.7 \mathrm{a}$ & $0.9 \mathrm{a}$ & $9.6 \mathrm{a}$ & $15.7 \mathrm{a}$ & $0.9 \mathrm{a}$ & $8.6 \mathrm{a}$ & $13.7 \mathrm{a}$ \\
\hline Thiram & $0.2 \mathrm{a}$ & $1.1 \mathrm{a}$ & $5.7 \mathrm{a}$ & $3.4 \mathrm{ab}$ & $7.0 \mathrm{a}$ & $24.2 \mathrm{~b}$ & $2.8 \mathrm{ab}$ & $6.1 \mathrm{a}$ & $20.3 \mathrm{~b}$ \\
\hline Iprodione & $\ldots$ & $7.6 \mathrm{c}$ & $12.3 \mathrm{~b}$ & $\ldots$ & $16.3 \mathrm{~b}$ & $30.1 \mathrm{c}$ & $\ldots$ & $15.1 \mathrm{~b}$ & $26.2 \mathrm{c}$ \\
\hline \multicolumn{10}{|l|}{ Yield (kg/ha) } \\
\hline Control & $5,765 \mathrm{nd}$ & $4,619 \mathrm{c}$ & $3,980 \mathrm{c}$ & $16,660 \mathrm{nd}$ & $11,991 \mathrm{~b}$ & $4,860 \mathrm{c}$ & 22,425 nd & $16,610 \mathrm{~d}$ & $8,840 \mathrm{~d}$ \\
\hline Captan & 6,555 & $5,591 \mathrm{~b}$ & $6,512 \mathrm{a}$ & 19,091 & $18,082 \mathrm{a}$ & $13,594 \mathrm{a}$ & 25,645 & $23,672 b$ & $20,106 \mathrm{a}$ \\
\hline Captan + iprodione & 6,280 & 6,558 a & $6,169 \mathrm{ab}$ & 18,483 & $20,912 \mathrm{a}$ & $13,746 \mathrm{a}$ & 24,763 & $27,470 \mathrm{a}$ & $19,915 \mathrm{a}$ \\
\hline Thiram & 7,664 & $5,286 \mathrm{bc}$ & $5,512 a b c$ & 16,523 & $20,295 \mathrm{a}$ & $9,750 \mathrm{~b}$ & 24,188 & $25,581 \mathrm{ab}$ & $15,261 \mathrm{~b}$ \\
\hline Iprodione & $\ldots$ & $5,472 \mathrm{~b}$ & $4,681 \mathrm{bc}$ & $\ldots$ & $14,807 \mathrm{~b}$ & $7,811 \mathrm{~b}$ & $\ldots$ & $20,279 \mathrm{c}$ & $12,492 \mathrm{c}$ \\
\hline
\end{tabular}

${ }^{v}$ Means followed by different letters within a column in each section are significantly different as determined by Fishers protected least significant difference test $(P \leq 0.05) ; \ldots=$ treatment not evaluated that season; $\mathrm{nd}=$ mean separations were not made because the overall treatment effect was not significant.

${ }^{\text {w}}$ Early period represents fruit harvested from the first peak bloom each season: harvest weeks 1 to 8 in $1995-96$, weeks 1 to 5 in $1996-97$, and weeks 1 to 7 in 1997-98.

${ }^{x}$ Late period represents fruit harvested from the second peak bloom each season: harvest weeks 9 to 17 in 1995-96, weeks 6 to 12 in 1996-97, and weeks 8 to 15 in $1997-98$.

y Whole-season period is the combined harvests from both the early and late periods.

${ }^{\mathrm{z}}$ Botrytis fruit rot incidence is expressed as the percentage of marketable and unmarketable fruit harvested with Botrytis rot. Control $=$ untreated; Captan $=$ weekly applications of captan; Captan + iprodione $=$ applications of captan plus four bloom applications of iprodione; Thiram = weekly applications of thiram; Iprodione $=$ four bloom applications of iprodione.

Table 2. Repeated measures analysis of variance describing effects of fungicide treatments on weekly and cumulative incidence of Botrytis fruit rot and marketable yield of strawberry during the 1995-96, 1996-97, and 1997-98 seasons ${ }^{\mathrm{x}}$

\begin{tabular}{|c|c|c|c|c|c|c|c|c|c|c|c|c|c|c|c|}
\hline \multirow[b]{3}{*}{ Variations } & \multicolumn{5}{|c|}{ 1995-96 season } & \multicolumn{5}{|c|}{ 1996-97 season } & \multicolumn{5}{|c|}{ 1997-98 season } \\
\hline & \multirow[b]{2}{*}{ df } & \multicolumn{2}{|c|}{ Weekly $^{y}$} & \multicolumn{2}{|c|}{ Cumulative $^{\mathrm{z}}$} & \multirow[b]{2}{*}{ df } & \multicolumn{2}{|c|}{ Weekly } & \multicolumn{2}{|c|}{ Cumulative } & \multirow[b]{2}{*}{ df } & \multicolumn{2}{|c|}{ Weekly } & \multicolumn{2}{|c|}{ Cumulative } \\
\hline & & MS & $P>F$ & MS & $P>F$ & & MS & $P>F$ & MS & $P>F$ & & MS & $P>F$ & MS & $P>F$ \\
\hline \multicolumn{16}{|l|}{ Rot incidence } \\
\hline Block & 3 & 0.0791 & 0.5323 & 0.0570 & 0.6876 & 3 & 0.0464 & 0.2578 & 0.0391 & 0.2938 & 3 & 0.0618 & 0.2744 & 0.0329 & 0.5431 \\
\hline Treatment & 3 & 0.5425 & 0.0214 & 0.7419 & 0.0120 & 4 & 0.4546 & 0.0010 & 0.3436 & 0.0003 & 5 & 0.6628 & 0.0001 & 0.4758 & 0.0002 \\
\hline Error & 9 & 0.3027 & $\ldots$ & 0.3381 & $\ldots$ & 12 & 0.0304 & $\ldots$ & 0.0281 & $\ldots$ & 15 & 0.0433 & $\ldots$ & 0.0444 & $\ldots$ \\
\hline Time & 14 & 0.0768 & 0.0001 & 0.4067 & 0.0001 & 9 & 0.5049 & 0.0001 & 0.1892 & 0.0001 & 14 & 0.9501 & 0.0001 & 0.4666 & 0.0001 \\
\hline Time $\times$ block & 42 & 0.3101 & 0.2526 & 0.0020 & 0.0111 & 27 & 0.0103 & 0.7690 & 0.0013 & 0.7634 & 42 & 0.0313 & 0.1051 & 0.0054 & 0.5312 \\
\hline Time $\times$ treatment & 42 & 0.3921 & 0.0624 & 0.0008 & 0.5929 & 36 & 0.0316 & 0.0003 & 0.0032 & 0.0378 & 70 & 0.0336 & 0.0332 & 0.0065 & 0.3440 \\
\hline Error & 126 & 0.7831 & $\ldots$ & 0.0009 & $\ldots$ & 108 & 0.0132 & $\ldots$ & 0.0018 & $\ldots$ & 210 & 0.0232 & $\ldots$ & 0.0058 & $\ldots$ \\
\hline \multicolumn{16}{|l|}{ Marketable yield } \\
\hline Block & 3 & $5.0 \times 10^{5}$ & 0.6325 & $3.1 \times 10^{7}$ & 0.6773 & 3 & $7.7 \times 10^{4}$ & 0.8915 & $3.0 \times 10^{6}$ & 0.6743 & 3 & $7.9 \times 10^{5}$ & 0.0032 & $2.9 \times 10^{7}$ & 0.0539 \\
\hline Treatment & 3 & $4.3 \times 10^{5}$ & 0.6766 & $3.5 \times 10^{7}$ & 0.6365 & 4 & $6.2 \times 10^{6}$ & 0.0001 & $1.0 \times 10^{8}$ & 0.0001 & 5 & $5.0 \times 10^{6}$ & 0.0001 & $1.4 \times 10^{8}$ & 0.0001 \\
\hline Error & 9 & $8.3 \times 10^{5}$ & $\ldots$ & $6.0 \times 10^{7}$ & $\ldots$ & 12 & $3.8 \times 10^{5}$ & $\ldots$ & $5.7 \times 10^{6}$ & $\ldots$ & 15 & $1.1 \times 10^{5}$ & $\ldots$ & $8.9 \times 10^{6}$ & $\ldots$ \\
\hline Time & 16 & $2.2 \times 10^{7}$ & 0.0001 & $1.2 \times 10^{9}$ & 0.0001 & 11 & $4.3 \times 10^{7}$ & 0.0001 & $1.1 \times 10^{10}$ & 0.0001 & 14 & $7.9 \times 10^{6}$ & 0.0001 & $4.9 \times 10^{8}$ & 0.0001 \\
\hline Time $\times$ block & 48 & $2.7 \times 10^{5}$ & 0.7784 & $1.3 \times 10^{6}$ & 0.9549 & 33 & $5.3 \times 10^{5}$ & 0.0064 & $9.1 \times 10^{5}$ & 0.4491 & 42 & $1.8 \times 10^{5}$ & 0.0381 & $1.4 \times 10^{6}$ & 0.0001 \\
\hline Time $\times$ treatment & 48 & $3.9 \times 10^{5}$ & 0.4964 & $1.8 \times 10^{6}$ & 0.8011 & 44 & $8.3 \times 10^{5}$ & 0.0001 & $9.1 \times 10^{5}$ & 0.0001 & 70 & $3.6 \times 10^{5}$ & 0.0001 & $8.0 \times 10^{6}$ & 0.0001 \\
\hline Error & 144 & $4.0 \times 10^{5}$ & $\ldots$ & $2.9 \times 10^{6}$ & $\ldots$ & 132 & $2.6 \times 10^{5}$ & $\ldots$ & $9.1 \times 10^{5}$ & $\ldots$ & 210 & $1.1 \times 10^{5}$ & $\ldots$ & $3.7 \times 10^{5}$ & $\ldots$ \\
\hline
\end{tabular}

${ }^{\mathrm{x}} \mathrm{df}=$ Degrees of freedom, MS = mean square, and $P=$ probability values associated with the $F$ tests. Analysis of variance for Botrytis incidence was performed on arcsine square root transformed data.

y Data were from each individual harvest week.

${ }^{\mathrm{z}}$ Data were cumulative totals from that week and all previous weeks. 
marketable yield. The incidence of Botrytis fruit rot was significantly affected by treatment for both the weekly and cumulative data each season $(P \leq 0.0214$; Table 2$)$ with the repeated measures analysis of variance. A highly significant time effect $(P=0.0001)$ for both weekly and cumulative data were found in all three seasons. Significant time-treatment effects were found for both the weekly $(P=0.0003)$ and cumulative $(P=0.0378)$ data for $1996-97$ and for the weekly data during 1997-98 ( $P$ $=0.0332)$. Marketable yield was significantly affected by treatment $(P=0.0001)$ for weekly and cumulative data during 1996-97 and 1997-98.

Data were analyzed for each harvest week individually and cumulatively (all harvests up to and including that week). During 1995-96, significant treatment differences in the weekly incidence of Botrytis fruit rot occurred during weeks 11, 12 , and 14 , whereas significant differences in weekly yield only occurred during week 15 (Table 3). Significant treatment effects $(P \leq 0.05)$ on cumulative Botrytis fruit rot incidence were found from harvest week 4 to the end of the season. However, there were no significant treatment effects on cumulative yield. During 1996-97, significant treatment effects on the weekly incidence of Botrytis fruit rot were found for most of the season after week 3 (Table 4).
However, weekly marketable yield was not consistently affected by treatment until the final 3 weeks. Cumulative marketable yield and incidence of Botrytis fruit rot were significantly affected by treatment from week 3 (yield) or week 4 (Botrytis fruit rot) through the end of the season. During 1997-98, weekly and cumulative incidence of Botrytis fruit rot were significantly affected by treatment from week 6 and week 5, respectively, for most of the season (Table 5). Weekly marketable yield was not consistently affected by treatment until 5 of the last 6 weeks of the season, but cumulative marketable yield was significantly affected by treatment from week 4 through the end of the season.

There were almost no significant differences in weekly or cumulative incidence of Botrytis fruit rot or marketable yield between the captan and captan plus iprodione treatments during 1995-96 and 1997-98 (Tables 3 and 5). During the 1996-97 season, there were also no significant differences between the captan and the captan plus iprodione treatments for most comparisons of weekly or cumulative incidence of Botrytis fruit rot and weekly yield (Table 4). However, plants treated with captan plus iprodione had significantly higher cumulative yield than plants treated with only captan from week 4 through the end of the season.
The first two bloom applications in the iprodione only treatment did not reduce the incidence of Botrytis compared to the untreated control during 1996-97 or 1997-98 (Tables 4 and 5). However, the second two iprodione bloom applications (week 5 to 6 in 1996-97 and week 7 to 8 in 1997-98) significantly reduced the weekly incidence of Botrytis fruit rot both seasons. Significant effects from the iprodione only treatment were observed 1,3 , and 5 weeks after applications began in 1996-97 and after 3 $(P=0.0582)$ and 4 weeks in 1997-98. In 1997-98, the weekly incidence of Botrytis fruit rot in the iprodione only treatment was also significantly lower than the control during week 15 and unexpectedly higher a week before the second set of bloom applications began (week 6).

During the harvest of the first fruit set, weekly marketable yields for plants treated with iprodione were significantly higher than the control plants during week 3 in both 1996-97 and 1997-98 (Tables 4 and 5). However, there were no significant differences in weekly incidence of Botrytis fruit rot between the plants treated with iprodione and the control plants during week 3. During harvest of the second fruit set, weekly marketable yield was significantly higher for plants treated with iprodione than the control plants during week 10 in $1996-97$ and week 10 and 11 in

Table 3. Weekly and cumulative harvest data and multiple mean comparisons for Botrytis fruit rot incidence and marketable yield for the 1995-96 season ${ }^{\mathrm{x}}$

\begin{tabular}{|c|c|c|c|c|c|c|c|c|c|c|c|c|c|c|c|c|c|}
\hline \multirow[b]{2}{*}{ Treatment $^{\mathrm{z}}$} & \multicolumn{17}{|c|}{ Harvest week $^{y}$} \\
\hline & 1 & 2 & 3 & 4 & 5 & 6 & 7 & 8* & 9* & 10 & 11 & 12 & 13 & 14 & 15 & 16 & 17 \\
\hline \multicolumn{18}{|l|}{ Rot incidence } \\
\hline \multicolumn{18}{|l|}{ Weekly } \\
\hline Control & 0 & 0 & 2.0 & 3.6 & 3.2 & 5.8 & 4.4 & 1.3 & 2.3 & 0.8 & $17.8 \mathrm{~b}$ & $9.4 \mathrm{c}$ & 3.8 & $12.4 \mathrm{~b}$ & 0.5 & 1.5 & 1.0 \\
\hline Captan & 0 & 0 & 0 & 0 & 1.3 & 0 & 0 & 0 & 0 & 0 & $2.4 \mathrm{a}$ & $3.1 \mathrm{bc}$ & 1.6 & $1.6 \mathrm{a}$ & 1.4 & 0.5 & 0.6 \\
\hline Cap + ipro & 0 & 0 & 0 & 0 & 0 & 0 & 1.4 & 0 & 0 & 0 & $4.1 \mathrm{a}$ & $0 \mathrm{a}$ & 0.7 & $1.9 \mathrm{a}$ & 0 & 0.2 & 0 \\
\hline Thiram & 0 & 0 & 0 & 0 & 1.3 & 0 & 0 & 0 & 1.3 & 0.5 & $6.4 \mathrm{a}$ & $4.1 \mathrm{ab}$ & 5.5 & $3.6 \mathrm{a}$ & 1.4 & 1.2 & 0.9 \\
\hline$P$ & $\ldots$ & $\ldots$ & 0.0880 & 0.4363 & 0.3890 & 0.0927 & 0.2701 & 0.4363 & 0.6231 & 0.4363 & 0.0236 & 0.0147 & 0.2268 & 0.0035 & 0.3615 & 0.5910 & 0.7837 \\
\hline \multicolumn{18}{|l|}{ Cumulative } \\
\hline Control & 0 & 0 & 1.2 & $1.6 \mathrm{~b}$ & $1.9 \mathrm{~b}$ & $2.4 \mathrm{~b}$ & $2.6 \mathrm{~b}$ & $2.5 \mathrm{~b}$ & $2.4 \mathrm{~b}$ & $2.2 \mathrm{~b}$ & $5.0 \mathrm{~b}$ & $6.1 \mathrm{~b}$ & $5.2 \mathrm{~b}$ & $6.9 \mathrm{~b}$ & $6.2 \mathrm{~b}$ & $5.5 \mathrm{~b}$ & $5.3 \mathrm{~b}$ \\
\hline Captan & 0 & 0 & 0 & $0 \mathrm{a}$ & $0.3 \mathrm{a}$ & $0.3 \mathrm{a}$ & $0.3 \mathrm{a}$ & $0.2 \mathrm{a}$ & $0.2 \mathrm{a}$ & $0.1 \mathrm{a}$ & $0.7 \mathrm{a}$ & $1.2 \mathrm{a}$ & $1.4 \mathrm{a}$ & $1.5 \mathrm{a}$ & $1.5 \mathrm{a}$ & $1.3 \mathrm{a}$ & $1.3 \mathrm{a}$ \\
\hline Cap + ipro & 0 & 0 & 0 & $0 \mathrm{a}$ & $0 \mathrm{a}$ & $0 \mathrm{a}$ & $0.3 \mathrm{a}$ & $0.2 \mathrm{a}$ & $0.2 \mathrm{a}$ & $0.2 \mathrm{a}$ & $1.0 \mathrm{a}$ & $0.8 \mathrm{a}$ & $0.8 \mathrm{a}$ & $1.2 \mathrm{a}$ & $1.1 \mathrm{a}$ & $1.0 \mathrm{a}$ & $0.9 \mathrm{a}$ \\
\hline Thiram & 0 & 0 & 0 & $0 \mathrm{a}$ & $0.4 \mathrm{a}$ & $0.3 \mathrm{a}$ & $0.3 \mathrm{a}$ & $0.2 \mathrm{a}$ & $0.3 \mathrm{a}$ & $0.4 \mathrm{a}$ & $1.4 \mathrm{a}$ & $2.0 \mathrm{a}$ & $3.3 \mathrm{ab}$ & $3.3 \mathrm{ab}$ & $3.1 \mathrm{ab}$ & $2.9 \mathrm{ab}$ & $2.8 \mathrm{ab}$ \\
\hline$P$ & $\ldots$ & $\ldots$ & 0.0877 & 0.0046 & 0.0087 & 0.0054 & 0.0169 & 0.0121 & 0.0242 & 0.0211 & 0.0170 & 0.0190 & 0.0711 & 0.0301 & 0.0366 & 0.0438 & 0.0417 \\
\hline \multicolumn{18}{|l|}{ Yield (kg/ha) } \\
\hline \multicolumn{18}{|l|}{ Weekly } \\
\hline Control & 75 & 962 & 1,754 & 364 & 712 & 342 & 665 & 892 & 1,202 & 864 & 1,613 & 3,749 & 5,626 & 1,855 & $356 \mathrm{~b}$ & 1,119 & 276 \\
\hline Captan & 54 & 982 & 2,072 & 473 & 571 & 160 & 1,131 & 1,111 & 2,343 & 1,462 & 2,439 & 2,877 & 4,703 & 2,397 & $935 \mathrm{a}$ & 1,440 & 494 \\
\hline Cap + ipro & 39 & 780 & 1,784 & 477 & 1,026 & 337 & 955 & 883 & 1,797 & 1,362 & 1,920 & 3,029 & 4,612 & 2,511 & $1,003 \mathrm{a}$ & 1,647 & 601 \\
\hline Thiram & 69 & 1,092 & 1,610 & 401 & 1,142 & 632 & 1,401 & 1,317 & 1,921 & 1,620 & 2,082 & 3,080 & 4,113 & 1,922 & $420 \mathrm{~b}$ & 870 & 496 \\
\hline$P$ & 0.9336 & 0.6959 & 0.7419 & 0.6999 & 0.1470 & 0.2708 & 0.2166 & 0.6737 & 0.2611 & 0.1813 & 0.2074 & 0.6315 & 0.7107 & 0.3434 & 0.0002 & 0.0703 & 0.0715 \\
\hline \multicolumn{18}{|c|}{ 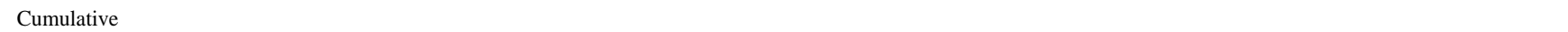 } \\
\hline Control & 75 & 1,037 & 2,790 & 3,154 & 3,866 & 4,208 & 4,873 & 5,765 & 6,967 & 7,831 & 9,444 & 13,193 & 18,819 & 20,674 & 21,030 & 22,149 & 22,425 \\
\hline Captan & 54 & 1,036 & 3,108 & 3,581 & 4,152 & 4,312 & 5,443 & 6,555 & 8,897 & 10,360 & 12,799 & 15,676 & 20,379 & 22,776 & 23,711 & 25,151 & 25,645 \\
\hline Cap + ipro & 39 & 818.7 & 2,602 & 3,080 & 4,106 & 4,442 & 5,397 & 6,280 & 8,077 & 9,438 & 11,359 & 14,388 & 19,000 & 21,511 & 22,515 & 24,162 & 24,763 \\
\hline Thiram & 69 & 1,161 & 2,771 & 3,172 & 4,314 & 4,947 & 6,347 & 7,664 & 9,585 & 11,205 & 13,286 & 16,366 & 20,479 & 22,401 & 22,821 & 23,692 & 24,188 \\
\hline$P$ & 0.9336 & 0.6999 & 0.8494 & 0.7761 & 0.8976 & 0.7566 & 0.4609 & 0.4807 & 0.4380 & 0.3580 & 0.3185 & 0.4627 & 0.8618 & 0.8666 & 0.7919 & 0.7154 & 0.6766 \\
\hline
\end{tabular}

${ }^{\mathrm{x}}$ Means followed by different letters within a column in each section are significantly different as determined by Fishers protected least significant difference test $(P \leq 0.05) ; . . .=$ analysis not done because no fruit infected with Botrytis rot were harvested that week.

y Calendar week that harvest data were collected. Date for the Sunday beginning each week: $1=3$ Dec, $2=10$ Dec, $3=17$ Dec, $4=24$ Dec, $5=31$ Dec, $6=7$ Jan, $7=14$ Jan, $8=$ $21 \mathrm{Jan}, 9=28 \mathrm{Jan}, 10=4 \mathrm{Feb}, 11=11 \mathrm{Feb}, 12=18 \mathrm{Feb}, 13=25 \mathrm{Feb}, 14=3 \mathrm{Mar}, 15=10 \mathrm{Mar}, 16=17 \mathrm{Mar}$, and $17=24 \mathrm{Mar}$. The second set of bloom fungicide applications were made in weeks marked with "*".

${ }^{\mathrm{z}}$ Botrytis fruit rot incidence values are expressed as the percentage of marketable and unmarketable fruit harvested with Botrytis rot. Weekly $=$ data for analysis were from each individual harvest week Control = untreated; Captan = weekly applications of captan; Cap + ipro $=$ applications of captan plus four bloom applications of iprodione; Thiram = weekly applications of thiram. $P$ indicates significant probability values associated with the $F$ tests; analysis of variance for Botrytis incidence was performed on arcsine square root transformed data. Cumulative $=$ data for analysis a cumulative total from that week and all previous weeks. 
1997-98. The higher yields corresponded with significantly lower incidence of Botrytis fruit rot for the iprodione-treated plants than the control plants during those weeks. Cumulative yields were significantly higher for the iprodione treatment than the control from week 3 to 6 and from week 8 to the end of the season during 1996-97 and from week 11 to the end of the season during 1997-98.

\section{DISCUSSION}

Weekly applications of the protectant fungicides captan and thiram provided significant control of Botrytis fruit rot and increased marketable yield of annual strawberry in this study. The effectiveness of captan and thiram were similar the first two seasons, but captan was more effective the third season. Early-season fungicide applications did not control Botrytis fruit rot until at least the fourth week of harvest, 9 to 10 weeks after applications began. Bloom applications of iprodione also reduced the incidence of Botrytis fruit rot, but only for applications made during the second peak bloom. The control of Botrytis fruit rot by weekly captan applications was not improved by the addition of iprodione bloom applications.

Although applications of iprodione during the second peak bloom period reduced the incidence of Botrytis fruit rot, applications made during the first peak bloom did not. The reduction in Botrytis fruit rot corresponded with higher whole-season marketable yields compared to the control. Interestingly, marketable yield was also higher for iprodione-treated plants during the early period of 1996-97 despite no reduction in Botrytis fruit rot compared to the control. In addition to rotting fruit as they mature, $B$. cinerea can also cause a flower blight and rot immature fruit (18). When flowers or young fruit are killed by Botrytis fruit rot, they are not harvested. These diseased fruit are therefore not included in the incidence values for Botrytis fruit rot. We hypothesize that the observed increases in marketable yield when there was no reduction in fruit rot was due to the control of Botrytis rot of immature fruit.

Fruit infection by $B$. cinerea typically begin in stamens, petals, and other floral parts $(7,21)$. The pathogen invades the receptacle as it ripens, ultimately causing
Botrytis rot (23). The purpose of targeting applications of iprodione to peak bloom periods was to protect the maximum number of flowers during each peak bloom. This approach has successfully controlled Botrytis fruit rot in perennial strawberry production systems (25). The effect of iprodione applications on Botrytis fruit rot should become apparent in 3 to 4 weeks, as the treated flowers mature into harvestable fruit (J. C. Mertely and D, E, Legard, unpublished data). As expected, control of Botrytis fruit rot developed 3 weeks after the start of the second set of bloom applications in 1997-98. However, in 1996-97, control was observed only 1 week after the start of the second set of bloom applications, suggesting that iprodione controls Botrytis rot infections after flowering. This is not completely unexpected because iprodione has some systemic activity $(1,20)$.

Annual strawberry production in Florida is dependent upon regular fungicide applications to control Botrytis fruit rot and other diseases. A typical commercial control program consists of weekly applications of captan or thiram supplemented by

Table 4. Weekly and cumulative harvest data and multiple mean comparisons for Botrytis fruit rot incidence and marketable yield for the 1996-97 season ${ }^{\mathrm{x}}$

\begin{tabular}{|c|c|c|c|c|c|c|c|c|c|c|c|c|}
\hline \multirow[b]{2}{*}{ Treatment $^{\mathrm{z}}$} & \multicolumn{12}{|c|}{ Harvest week $^{\mathbf{y}}$} \\
\hline & 1 & 2 & 3 & 4 & $5 *$ & $6^{*}$ & 7 & 8 & 9 & 10 & 11 & 12 \\
\hline \multicolumn{13}{|l|}{ Rot incidence } \\
\hline \multicolumn{13}{|l|}{ Weekly } \\
\hline Control & 0 & 0 & 7.4 & $8.1 \mathrm{c}$ & 2.5 & $28.4 \mathrm{~b}$ & $53.0 \mathrm{c}$ & $40.0 \mathrm{c}$ & $13.2 \mathrm{~b}$ & $40.9 \mathrm{c}$ & $19.9 \mathrm{~b}$ & 3.8 \\
\hline Captan & 0 & 0 & 1.8 & $0.7 \mathrm{a}$ & 1.9 & $0 \mathrm{a}$ & $29.2 \mathrm{bc}$ & $12.2 \mathrm{ab}$ & $6.7 \mathrm{ab}$ & $17.3 \mathrm{ab}$ & $10.9 \mathrm{ab}$ & 3.3 \\
\hline Cap + ipro & 0 & 0 & 2.3 & $4.7 \mathrm{bc}$ & 3.6 & $0 \mathrm{a}$ & $23.9 \mathrm{~b}$ & $16.0 \mathrm{ab}$ & $1.7 \mathrm{a}$ & $16.2 \mathrm{ab}$ & $10.4 \mathrm{a}$ & 4.7 \\
\hline Thiram & 0 & 0 & 1.7 & $1.6 \mathrm{ab}$ & 0.0 & $0 \mathrm{a}$ & $6.5 \mathrm{a}$ & $9.6 \mathrm{a}$ & $4.3 \mathrm{a}$ & $10.3 \mathrm{a}$ & $9.1 \mathrm{a}$ & 3.3 \\
\hline Iprodione & 0 & 0 & 5.1 & $8.9 \mathrm{c}$ & 10.3 & $5.9 \mathrm{a}$ & $30.6 \mathrm{bc}$ & $23.3 \mathrm{~b}$ & $12.1 \mathrm{~b}$ & $24.2 \mathrm{~b}$ & $19.6 \mathrm{~b}$ & 4.1 \\
\hline$P$ & $\ldots$ & $\ldots$ & 0.2207 & 0.0287 & 0.6122 & 0.0002 & 0.0098 & 0.0008 & 0.0177 & 0.0003 & 0.0400 & 0.8934 \\
\hline \multicolumn{13}{|l|}{ Cumulative } \\
\hline Control & 0 & 0 & 4.9 & $6.6 \mathrm{~b}$ & $6.0 \mathrm{~b}$ & $7.1 \mathrm{~b}$ & $15.1 \mathrm{c}$ & $22.2 \mathrm{~d}$ & $19.6 \mathrm{c}$ & $26.3 \mathrm{~d}$ & $24.5 \mathrm{c}$ & $20.7 \mathrm{c}$ \\
\hline Captan & 0 & 0 & 1.0 & $1.0 \mathrm{a}$ & $1.2 \mathrm{a}$ & $1.0 \mathrm{a}$ & $4.5 \mathrm{ab}$ & $7.0 \mathrm{ab}$ & $6.9 \mathrm{a}$ & $10.0 \mathrm{~b}$ & $10.2 \mathrm{a}$ & $8.6 \mathrm{a}$ \\
\hline Cap + ipro & 0 & 0 & 1.5 & $2.7 \mathrm{ab}$ & $2.6 \mathrm{ab}$ & $2.4 \mathrm{ab}$ & $4.9 \mathrm{~b}$ & $8.0 \mathrm{bc}$ & $6.0 \mathrm{a}$ & $9.3 \mathrm{ab}$ & $9.6 \mathrm{a}$ & $8.6 \mathrm{a}$ \\
\hline Thiram & 0 & 0 & 1.1 & $1.3 \mathrm{a}$ & $1.1 \mathrm{a}$ & $1.0 \mathrm{a}$ & $1.6 \mathrm{a}$ & $4.3 \mathrm{a}$ & $4.2 \mathrm{a}$ & $6.1 \mathrm{a}$ & $7.0 \mathrm{a}$ & $6.1 \mathrm{a}$ \\
\hline Iprodione & 0 & 0 & 3.5 & $5.8 \mathrm{~b}$ & $7.6 \mathrm{~b}$ & $7.6 \mathrm{~b}$ & $10.1 \mathrm{bc}$ & $13.6 \mathrm{c}$ & $13.0 \mathrm{~b}$ & $16.7 \mathrm{c}$ & $17.4 \mathrm{~b}$ & $15.1 \mathrm{~b}$ \\
\hline$P$ & $\ldots$ & $\ldots$ & 0.1890 & 0.0176 & 0.0226 & 0.0079 & 0.0013 & 0.0001 & 0.0001 & 0.0001 & 0.0001 & 0.0001 \\
\hline \multicolumn{13}{|l|}{ Yield (kg / ha) } \\
\hline \multicolumn{13}{|l|}{ Weekly } \\
\hline Control & 430 & 833 & $2,098 \mathrm{~b}$ & 933 & 326 & 75 & 352 & 1,826 & 3,499 & $2,578 \mathrm{c}$ & $1,920 \mathrm{~b}$ & $1,742 \mathrm{bc}$ \\
\hline Captan & 545 & 984 & $2,349 \mathrm{ab}$ & 1,323 & 390 & 202 & 528 & 2,785 & 3,959 & $4,048 \mathrm{~b}$ & $3,925 \mathrm{a}$ & $2,635 \mathrm{a}$ \\
\hline Cap + ipro & 547 & 1,011 & $2,619 \mathrm{a}$ & 1,840 & 541 & 392 & 730 & 3,354 & 5,166 & $4,910 \mathrm{a}$ & $3,979 \mathrm{a}$ & $2,382 \mathrm{ab}$ \\
\hline Thiram & 367 & 948 & $2,150 \mathrm{~b}$ & 1,257 & 564 & 243 & 742 & 2,672 & 4,200 & $4,669 \mathrm{ab}$ & $4,879 \mathrm{a}$ & 2,889 a \\
\hline Iprodione & 509 & 866 & $2,597 \mathrm{a}$ & 1,060 & 439 & 149 & 282 & 2,365 & 4,578 & $3,958 \mathrm{~b}$ & $2,306 \mathrm{~b}$ & $1,169 \mathrm{c}$ \\
\hline$P$ & 0.6828 & 0.4829 & 0.0269 & 0.0776 & 0.3665 & 0.2578 & 0.2858 & 0.0609 & 0.2136 & 0.0006 & 0.0023 & 0.0061 \\
\hline \multicolumn{13}{|l|}{ Cumulative } \\
\hline Control & 430 & 1,262 & $3,360 \mathrm{c}$ & $4,293 \mathrm{c}$ & $4,619 \mathrm{c}$ & $4,693 \mathrm{c}$ & $5,045 \mathrm{c}$ & $6,871 \mathrm{c}$ & $10,369 \mathrm{c}$ & $12,948 \mathrm{c}$ & $14,867 \mathrm{~d}$ & $16,610 \mathrm{~d}$ \\
\hline Captan & 545 & 1,529 & $3,878 \mathrm{ab}$ & $5,201 \mathrm{~b}$ & $5,591 \mathrm{~b}$ & $5,793 \mathrm{~b}$ & $6,320 \mathrm{~b}$ & $9,105 \mathrm{~b}$ & $13,065 \mathrm{~b}$ & $17,112 \mathrm{~b}$ & $21,037 \mathrm{bc}$ & $23,672 \mathrm{~b}$ \\
\hline Cap + ipro & 547 & 1,558 & $4,177 \mathrm{a}$ & $6,017 \mathrm{a}$ & $6,558 \mathrm{a}$ & $6,950 \mathrm{a}$ & $7,680 \mathrm{a}$ & $11,034 \mathrm{a}$ & 16,199 a & $21,109 \mathrm{a}$ & $25,088 \mathrm{a}$ & $27,470 \mathrm{a}$ \\
\hline Thiram & 367 & 1,315 & $3,465 \mathrm{bc}$ & $4,722 b c$ & $5,286 \mathrm{bc}$ & $5,529 \mathrm{bc}$ & $6,271 \mathrm{~b}$ & $8,943 \mathrm{~b}$ & $13,143 \mathrm{~b}$ & $17,812 \mathrm{~b}$ & $22,691 \mathrm{ab}$ & $25,581 \mathrm{ab}$ \\
\hline Iprodione & 509 & 1,375 & $3,972 \mathrm{ab}$ & $5,033 \mathrm{~b}$ & $5,472 \mathrm{~b}$ & $5,621 \mathrm{~b}$ & $5,903 \mathrm{bc}$ & $8,268 \mathrm{~b}$ & $12,846 \mathrm{~b}$ & $16,804 \mathrm{~b}$ & $19,110 \mathrm{c}$ & $20,279 \mathrm{c}$ \\
\hline$P$ & 0.6828 & 0.3236 & 0.0217 & 0.0005 & 0.0015 & 0.0024 & 0.0010 & 0.0005 & 0.0007 & 0.0003 & 0.0003 & 0.0001 \\
\hline
\end{tabular}

${ }^{x}$ Means followed by different letters within a column in each section are significantly different as determined by Fishers protected least significant difference test $(P \leq 0.05) \ldots=$ analysis not done because no fruit infected with Botrytis rot were harvested that week.

${ }^{y}$ Calendar week that harvest data were collected. Date for the Sunday beginning each week: $1=15 \mathrm{Dec}, 2=22 \mathrm{Dec}, 3=29 \mathrm{Dec}, 4=5 \mathrm{Jan}, 5=12 \mathrm{Jan}, 6=$ $19 \mathrm{Jan}, 7=26 \mathrm{Jan}, 8=2 \mathrm{Feb}, 9=9 \mathrm{Feb}, 10=16 \mathrm{Feb}, 11=23 \mathrm{Feb}$, and $12=2 \mathrm{Mar}$. The second set of bloom fungicide applicati ons were made in weeks marked with "*”".

${ }^{\mathrm{z}}$ Botrytis fruit rot incidence values are expressed as the percentage of marketable and unmarketable fruit harvested with Botrytis rot. Weekly $=$ Data for analysis was from each individual harvest week; Control = untreated; Captan = weekly applications of captan; Cap + ipro = applications of captan plus four bloom applications of iprodione; Thiram $=$ weekly applications of thiram; Iprodione $=$ four bloom applications of iprodione. $P=$ significant probability values associated with the $F$ tests; analysis of variance for Botrytis incidence was performed on arcsine square root transformed data. Cumulative $=$ data for analysis a cumulative total from that week and all previous weeks. 
applications of Botryticides during periods of high disease pressure. This program results in strawberries having the highest fungicide use of any food crop in Florida (22). The Food Quality Protection Act (FQPA) of 1996 requires increased pesticide safety consideration for infants and children. Strawberries are harvested directly into consumer packs without washing and are very popular with infants and children; therefore, implementation of the FQPA will likely have a significant effect on fungicide use on strawberry. To reduce child and infant exposure, the iprodione use label was changed to prohibit its application on flowering strawberries, effectively eliminating its use on strawberry. Fortunately, alternative Botryticides like fenhexamid are available. Recent field trials have shown that bloom applications of fenhexamid perform similarly to iprodione in controlling Botrytis fruit rot $(14,15)$.

Further implementation of the FQPA will likely affect the use of other fungicides on strawberry. It is prudent to develop disease management options for strawberry that will reduce fungicide use. By studying the dynamics of Botrytis fruit rot epidemics, we may be able to develop fungicide application schedules that reduce use and maintain control. In a standard commercial program, captan is applied weekly for five or six applications before the first harvest of the season. In this study, up to 10 captan or thiram applications were made before significant control of Botrytis fruit rot was observed. Typically, low levels of Botrytis fruit rot are observed early in the season. In two of the three seasons studied, no Botrytis fruit rot was observed until the third harvest week. These data suggest that weekly fungicide applications during the early season may not be necessary for the control of Botrytis fruit rot. If early fungicide applications are not critical for delaying the onset or reducing the severity of Botrytis fruit rot epidemics, then fewer applications or reduced rates during this period would lower fungicide usage. Epidemics of Botrytis fruit rot are typically most severe later in the season. Therefore, the effectiveness of bloom applications of Botryticides may be improved if they are focused on the second peak bloom period. Further research is needed to evaluate these approaches for controlling Botrytis fruit rot in annual strawberry.

\section{ACKNOWLEDGMENTS}

We thank D. Wenzel for his extensive assistance with this study; and L. Smith, J. Sumler, and C. Manley for their valuable assistance.

\section{LITERATURE CITED}

1. Adaskaveg, J. E., and Ogawa, J. M. 1994 Penetration of iprodione into mesocarp fruit tissue and suppression of gray mold and brown rot of sweet cherries. Plant Dis. 78:293-296.

2. Black, L. L., McInnes, T. B., and Gatti, J. M., Jr. 1990. Evaluation of fungicides for contro of strawberry fruit rots in Louisiana. Adv. Strawberry Prod. 9:33-36.

3. Braun, P. G., and Sutton, J. C. 1984. Effectiveness of fungicides in reducing inoculum production by Botrytis cinerea in dead strawberry leaves. Pages 971-976 in: Proc. Br. Crop Prot. Conf. Pests Dis. Vol. 3.

4. Braun, P. G., and Sutton, J. C. 1986. Management of strawberry gray mold with fungicides targeted against inoculum in crop residues. Pages 915-921 in: Proc. Br. Crop Prot. Conf. Pest Dis. Vol. 3.

5. Braun, P. G., and Sutton, J. C. 1987. Inoculum sources of Botrytis cinerea in fruit rot of strawberries in Ontario. Can. J. Plant Pathol. 9:1-5.

6. Braun, P. G., and Sutton, J. C. 1988. Infection cycles and population dynamics of Botrytis cinerea in strawberry leaves. Can. J. Plant Pathol. 10:133-141.

7. Bristow, P. R., McNicol, R. J., and Williamson, B. 1986. Infection of strawberry flowers by Botrytis cinerea and its relevance to gray mould development. Ann. Appl. Biol. 109:545-554.

8. Cambell, C. L., and Madden, L. V. 1990. Introduction to Plant Disease Epidemiology. J. Wiley \& Sons, New York.

9. Crandall, P. C., and Chamberlain, J. D. 1970.

Table 5. Weekly and cumulative harvest data and multiple mean comparisons for Botrytis fruit rot incidence and marketable yield for the 1997-98 season ${ }^{\mathrm{x}}$

\begin{tabular}{|c|c|c|c|c|c|c|c|c|c|c|c|c|c|c|c|}
\hline \multirow[b]{2}{*}{ Treatments $^{\mathrm{z}}$} & \multicolumn{15}{|c|}{ Harvest week $^{y}$} \\
\hline & 1 & 2 & 3 & 4 & 5 & 6 & $7 *$ & $8^{*}$ & 9 & 10 & 11 & 12 & 13 & 14 & 15 \\
\hline \multicolumn{16}{|l|}{ Rot incidence } \\
\hline \multicolumn{16}{|l|}{ Weekly } \\
\hline Control & 6.7 & 5.8 & 13.3 & 9.0 & 27.6 & $1.4 \mathrm{ab}$ & $24.7 \mathrm{~b}$ & 43.0 & 61.2 & 46.1 & $66.1 \mathrm{~b}$ & $50.0 \mathrm{c}$ & $52.7 \mathrm{c}$ & $25.7 \mathrm{~b}$ & $23.8 \mathrm{c}$ \\
\hline Captan & 4.1 & 0 & 5.0 & 1.6 & 1.9 & $4.4 \mathrm{bc}$ & $2.5 \mathrm{a}$ & 29.6 & 34.4 & 19.8 & $23.8 \mathrm{a}$ & $14.8 \mathrm{a}$ & $21.0 \mathrm{a}$ & $7.8 \mathrm{a}$ & $3.6 \mathrm{a}$ \\
\hline Cap + ipro & 9.2 & 0 & 2.1 & 3.1 & 8.3 & $8.6 \mathrm{bc}$ & $9.9 \mathrm{ab}$ & 27.1 & 33.4 & 12.0 & $20.0 \mathrm{a}$ & $18.1 \mathrm{ab}$ & $24.8 \mathrm{a}$ & $8.9 \mathrm{a}$ & $4.9 \mathrm{a}$ \\
\hline Thiram & 0 & 1.1 & 1.8 & 9.4 & 6.6 & $0.9 \mathrm{a}$ & $12.0 \mathrm{ab}$ & 27.0 & 33.6 & 25.8 & $28.9 \mathrm{a}$ & $35.2 \mathrm{bc}$ & $30.6 \mathrm{ab}$ & $14.7 \mathrm{a}$ & $13.1 \mathrm{~b}$ \\
\hline Iprodione & 2.8 & 7.6 & 5.4 & 7.6 & 20.1 & $15.0 \mathrm{c}$ & $21.1 \mathrm{~b}$ & 39.2 & 50.1 & 23.2 & $22.9 \mathrm{a}$ & $40.7 \mathrm{c}$ & $38.9 \mathrm{bc}$ & $25.7 \mathrm{~b}$ & $14.5 \mathrm{~b}$ \\
\hline$P$ & 0.6023 & 0.3334 & 0.5179 & 0.0980 & 0.1415 & 0.0155 & 0.0454 & 0.3756 & 0.1174 & 0.0582 & 0.0044 & 0.0049 & 0.0025 & 0.0031 & 0.0001 \\
\hline \multicolumn{16}{|l|}{ Cumulative } \\
\hline Control & 6.7 & 6.4 & 9.2 & 9.6 & $12.4 \mathrm{c}$ & $10.6 \mathrm{c}$ & $13.8 \mathrm{~b}$ & $17.9 \mathrm{~b}$ & $25.5 \mathrm{~b}$ & $27.3 \mathrm{~b}$ & $34.0 \mathrm{c}$ & $36.9 \mathrm{~d}$ & $40.7 \mathrm{c}$ & $37.5 \mathrm{~d}$ & $35.3 \mathrm{~d}$ \\
\hline Captan & 4.2 & 1.1 & 2.5 & 2.1 & $2.1 \mathrm{a}$ & $2.4 \mathrm{a}$ & $2.4 \mathrm{a}$ & $5.5 \mathrm{a}$ & $9.7 \mathrm{a}$ & $10.9 \mathrm{a}$ & $13.1 \mathrm{a}$ & $13.5 \mathrm{a}$ & $15.3 \mathrm{a}$ & $13.6 \mathrm{a}$ & $11.8 \mathrm{a}$ \\
\hline Cap + ipro & 9.2 & 3.1 & 2.7 & 3.0 & $3.2 \mathrm{ab}$ & $4.6 \mathrm{ab}$ & $5.7 \mathrm{a}$ & $8.8 \mathrm{a}$ & $12.5 \mathrm{a}$ & $12.4 \mathrm{a}$ & $13.6 \mathrm{a}$ & $14.7 \mathrm{ab}$ & $17.8 \mathrm{a}$ & $15.6 \mathrm{a}$ & $13.7 \mathrm{a}$ \\
\hline Thiram & 0 & 0.6 & 0.9 & 4.4 & $4.9 \mathrm{ab}$ & $4.3 \mathrm{ab}$ & $5.7 \mathrm{a}$ & $8.2 \mathrm{a}$ & $12.0 \mathrm{a}$ & $13.7 \mathrm{a}$ & $15.4 \mathrm{ab}$ & $20.4 \mathrm{bc}$ & $23.3 \mathrm{~b}$ & $21.8 \mathrm{~b}$ & $20.3 \mathrm{~b}$ \\
\hline Iprodione & 2.8 & 7.3 & 6.1 & 7.4 & $8.9 \mathrm{bc}$ & $9.6 \mathrm{bc}$ & $12.3 \mathrm{~b}$ & $16.7 \mathrm{~b}$ & $21.0 \mathrm{~b}$ & $21.6 \mathrm{~b}$ & $21.8 \mathrm{~b}$ & $23.2 \mathrm{c}$ & $28.8 \mathrm{~b}$ & $28.3 \mathrm{c}$ & $26.2 \mathrm{c}$ \\
\hline$P$ & 0.6023 & 0.3301 & 0.2751 & 0.1012 & 0.0204 & 0.0318 & 0.0011 & 0.0012 & 0.0047 & 0.0020 & 0.0008 & 0.0002 & 0.0001 & 0.0001 & 0.0001 \\
\hline \multicolumn{16}{|l|}{ Yield (kg/ha) } \\
\hline \multicolumn{16}{|l|}{ Weekly } \\
\hline Control & 441 & 890 & $353 \mathrm{~b}$ & $1,174 \mathrm{c}$ & 388 & 271 & 463 & 122 & 406 & $310 \mathrm{c}$ & $417 \mathrm{~b}$ & $1,117 \mathrm{c}$ & $748 c$ & $675 c$ & 1,064 \\
\hline Captan & 537 & 1,289 & $870 \mathrm{a}$ & $1,761 \mathrm{a}$ & 722 & 601 & 732 & 324 & 563 & $1,047 \mathrm{ab}$ & $1,584 \mathrm{a}$ & $3,030 \mathrm{a}$ & $3,121 \mathrm{a}$ & $1,946 \mathrm{a}$ & 1,978 \\
\hline Cap + ipro & 364 & 1,063 & $820 \mathrm{a}$ & $1,643 a b$ & 683 & 685 & 912 & 402 & 685 & $1,184 \mathrm{a}$ & $1,806 \mathrm{a}$ & $2,853 \mathrm{a}$ & $2,655 \mathrm{a}$ & $2,189 \mathrm{a}$ & 1,971 \\
\hline Thiram & 669 & 1,106 & $710 \mathrm{a}$ & $1,341 \mathrm{bc}$ & 602 & 544 & 540 & 246 & 611 & $903 \mathrm{~b}$ & $1,071 \mathrm{ab}$ & $2,005 \mathrm{~b}$ & $1,902 \mathrm{~b}$ & $1,388 \mathrm{~b}$ & 1,623 \\
\hline Iprodione & 412 & 1,235 & $719 a$ & $1,033 \mathrm{c}$ & 417 & 404 & 461 & 229 & 276 & $950 \mathrm{~b}$ & $1,496 \mathrm{a}$ & $1,850 \mathrm{bc}$ & $1,215 \mathrm{c}$ & $667 \mathrm{c}$ & 1,128 \\
\hline$P$ & 0.3637 & 0.5552 & 0.0125 & 0.0089 & 0.2687 & 0.0904 & 0.1225 & 0.4976 & 0.3801 & 0.0001 & 0.0129 & 0.0010 & 0.0001 & 0.0001 & 0.1705 \\
\hline \multicolumn{16}{|l|}{ Cumulative } \\
\hline Control & 441 & 1,331 & 1,684 & $2,858 \mathrm{c}$ & $3,246 \mathrm{c}$ & $3,517 \mathrm{c}$ & $3,980 \mathrm{c}$ & $4,103 \mathrm{c}$ & $4,508 \mathrm{c}$ & $4,819 \mathrm{c}$ & $5,235 \mathrm{c}$ & $6,353 \mathrm{c}$ & $7,101 \mathrm{c}$ & $7,775 \mathrm{~d}$ & $8,840 \mathrm{~d}$ \\
\hline Captan & 537 & 1,826 & 2,696 & $4,458 \mathrm{a}$ & $5,179 \mathrm{a}$ & $5,781 \mathrm{a}$ & $6,512 \mathrm{a}$ & $6,837 \mathrm{a}$ & $7,399 \mathrm{a}$ & $8,447 \mathrm{a}$ & $10,031 \mathrm{a}$ & $13,061 \mathrm{a}$ & $16,182 \mathrm{a}$ & $18,128 \mathrm{a}$ & $20,106 \mathrm{a}$ \\
\hline Cap + ipro & 364 & 1,426 & 2,246 & $3,889 \mathrm{ab}$ & $4,572 \mathrm{ab}$ & $5,257 \mathrm{ab}$ & $6,169 \mathrm{ab}$ & $6,571 \mathrm{a}$ & $7,256 \mathrm{a}$ & 8,441 a & $10,247 \mathrm{a}$ & $13,099 \mathrm{a}$ & $15,755 \mathrm{a}$ & 17,944 a & $19,915 \mathrm{a}$ \\
\hline Thiram & 669 & 1,775 & 2,485 & 3,826 abc & $4,428 \mathrm{abc}$ & $4,972 \mathrm{ab}$ & $5,512 a b c$ & $5,758 \mathrm{ab}$ & $6,369 a b$ & $7,272 \mathrm{ab}$ & $8,343 \mathrm{~b}$ & $10,348 \mathrm{~b}$ & $12,250 \mathrm{~b}$ & $13,638 \mathrm{~b}$ & $15,261 \mathrm{~b}$ \\
\hline Iprodione & 412 & 1,647 & 2,366 & $3,399 \mathrm{bc}$ & $3,816 \mathrm{bc}$ & $4,220 b c$ & $4,681 \mathrm{bc}$ & $4,910 \mathrm{bc}$ & $5,186 \mathrm{bc}$ & $6,136 \mathrm{bc}$ & $7,632 \mathrm{~b}$ & $9,482 \mathrm{~b}$ & $10,697 \mathrm{~b}$ & $11,364 \mathrm{c}$ & $12,492 \mathrm{c}$ \\
\hline$P$ & 0.3637 & 0.5544 & 0.0883 & 0.0434 & 0.0392 & 0.0351 & 0.0339 & 0.0178 & 0.0098 & 0.0019 & 0.0001 & 0.0001 & 0.0001 & 0.0001 & 0.0001 \\
\hline
\end{tabular}

${ }^{\mathrm{x}}$ Means followed by different letters within a column in each section are significantly different as determined by Fishers protected least significant difference test $(P \leq 0.05)$.

${ }^{y}$ Calendar week that harvest data were collected. Date for the Sunday beginning each week: $1=30$ Nov, $2=7$ Dec, $3=14$ Dec, $4=21$ Dec, $5=28$ Dec, $6=4$ Jan, $7=11$ Jan, $8=$ $18 \mathrm{Jan}, 9=25 \mathrm{Jan}, 10=1 \mathrm{Feb}, 11=8 \mathrm{Feb}, 12=15 \mathrm{Feb}, 13=22 \mathrm{Feb}, 14=1 \mathrm{Mar}$, and $15=8$ Mar. The second set of bloom fungicide applications were made in weeks marked with "*".

${ }^{\mathrm{z}}$ Botrytis fruit rot incidence values are expressed as the percentage of marketable and unmarketable fruit harvested with Botrytis rot. Weekly $=$ data for analysis was from each individual harvest week; Control $=$ untreated Captan = weekly applications of captan; Cap + ipro $=$ applications of captan plus bloom applications of iprodione; Thiram = weekly applications of thiram; Iprodione = bloom applications of iprodione. $\mathrm{P}=$ significant probability values associated with the $F$ tests; analysis of variance for Botrytis incidence was performed on arcsine square root transformed data. Cumulative $=$ data for analysis a cumulative total from that week and all previous weeks. 
Botrytis cinerea control with captan on strawberries. Plant Dis. Rep. 54:132-133.

10. Gill, J. L., 1978. Design and Analysis of Experiments in the Animal and Biomedical Sciences, Vol. 2. Iowa State University Press, Ames.

11. Howard, C. M., and Albregts, E. E. 1989. Evaluation of fungicides for control of strawberry gray mold and Phomopsis rot, 1988. Fungic. Nematic. Tests 44:94.

12. Howard, C. M., Chandler, C. K., and Albregts, E. E. 1990. Evaluation of fungicides for control of strawberry gray mold, 1989. Fungic. Nematic. Tests 45:92.

13. Jarvis, W. R. 1962. The infection of strawberry and raspberry fruits by Botrytis cinerea Fr. Ann. Appl. Biol. 50:569-575.

14. Legard, D. E., and Chandler, C. K. 1998. Evaluation of fungicides to control Botrytis fruit rot of Strawberry, 1997. Fungic. Nematic. Tests 53:121.

15. Legard, D. E., and Chandler, C. K. 2000. Evaluation of fungicides to control Botrytis fruit rot of strawberry, 1998. Fungic. Nematic. Tests. 55:124.
16. Legard, D. E., Xiao, C. L., Mertely, J. C., and Chandler, C. K. 2000. Effects of plant spacing and cultivar on the incidence of Botrytis fruit rot in annual strawberry. Plant Dis. 84:531538.

17. Legard, D. E., Xiao, C. L., Mertely, J. C., and Chandler, C. K. 2000. Efficacy of captan, thiram and iprodione for the control of Botrytis fruit rot on annual winter strawberry. (Abstr.) Phytopathology 90:S46.

18. Mass, J. L. 1998. Compendium of Strawberry Diseases, 2nd ed. Am. Phytopathol. Soc., St. Paul, MN.

19. Mertely, J. C., Chandler, C. K., Xiao, C. L., and Legard, D. E. Comparison of sanitation and fungicides for the management of Botrytis fruit rot of strawberry. Plant Dis. In press.

20. Osorio, J. M., Adaskaveg, J. E., Ogawa, J. M., Bostock, R. M., and Jones, A. D. 1994. Systemic activity and fungitoxicity of iprodione and E-0858 ( $N$-[5-(2-mthoxypridinyl)]-cyclopropane-carboxamide) in almond blossoms to Monilinia laxa. Phytopathology 84:656-660.

21. Powelson, R. L. 1960. Initiation of strawberry fruit rot caused by Botrytis cinerea. Phytopathology 50:491-494.

22. Smith, S. A., and Taylor, T. G. 1997. Production Costs for Selected Florida Vegetables 1996-97. Univ. Fla. Gainesville Fla. Coop Ext. Serv. Circ. 1202

23. Sutton, J. C. 1990. Epidemiology and management of Botrytis leaf blight of onion and gray mold of strawberry: a comparative analysis. Can. J. Plant Pathol. 12:100-110.

24. Washington, W. S., and Shanmuganathan, N 1993. Fungicidal control of strawberry fruit rots and strategies to combat dicarboximide resistance of Botrytis cinerea. Adv. Strawberry Res. 12:22-25.

25. Wilcox, W. F., and Seem, R. C. 1994. Relationship between strawberry gray mold incidence, environmental variables, and fungicide applications during different periods of the fruiting season. Phytopathology 84:264-270.

26. Xiao, C. L., Chandler, C. K., Price, J. F., and Legard, D. E. 1999. Comparative study on epidemics of strawberry fruit diseases under plastic tunnel and field production systems in Florida. (Abstr.) Phytopathology 89:S86. 